\title{
Hydrochemical characteristics of coastal aquifers of Kadaladi, Ramanathapuram District, Tamilnadu, India
}

\author{
P. Sivasubramanian • N. Balasubramanian • \\ John Prince Soundranayagam $\cdot$ N. Chandrasekar
}

Received: 9 October 2012/ Accepted: 27 May 2013/Published online: 20 June 2013

(C) The Author(s) 2013. This article is published with open access at Springerlink.com

\begin{abstract}
Geochemical signatures of groundwater in the coastal aquifers of Kadaladi block of Ramanathapuram District, Tamilnadu, India were used to identify the chemical processes that control hydrochemistry. The parameters such as $\mathrm{pH}, \mathrm{EC}$, TDS and major ion concentrations $\mathrm{Na}, \mathrm{K}, \mathrm{Ca}, \mathrm{Mg}, \mathrm{Cl}, \mathrm{HCO}_{3}, \mathrm{SO}_{4}, \mathrm{PO}_{4}$ and $\mathrm{NO}_{3}$ of the groundwater were analyzed. Abundances of these ions are in the following order $\mathrm{Na}>\mathrm{Ca}>\mathrm{Mg}>\mathrm{K}$ and $\mathrm{Cl}>\mathrm{HCO}_{3}>\mathrm{SO}_{4}>\mathrm{NO}_{3}>\mathrm{PO}_{4}$. Na-Cl is the dominant hydrochemical facies of the study area. Interpretation of the hydrochemical data suggests that hydrochemistry of the study area is controlled by mixing of fresh water with relict saline water, ion-exchange processes, silicate weathering and evaporation are responsible for the groundwater chemistry of the study area. Above statement is further supported by Gibbs plot where most of the samples fall within the evaporation zone. Good quality groundwater is restricted to coastal sand dunes running parallel to the coast and it is important to conserve these dunes.
\end{abstract}

Keywords Groundwater - Geochemical facies . Ionic ratios $\cdot$ Kadaladi Tamilnadu

P. Sivasubramanian $(\bowtie) \cdot$ N. Balasubramanian

Department of Geology, V. O. Chidambaram College,

Tuticorin 628008, India

e-mail: sivasubramanianvoc@gmail.com

J. P. Soundranayagam

Department of Physics, V. O. Chidambaram College,

Tuticorin 628008, India

N. Chandrasekar

Centre for GeoTechnology, Manonmaniam Sundaranar

University, Tirunelveli 627012, India

\section{Introduction}

Groundwater is the backbone of Indian agriculture and drinking water security. It is a common pool resource, used by millions of farmers across the country. Due to the ever increasing demand for potable and irrigation water and inadequacy of available surface water, the importance of groundwater is increasing exponentially every day (World Bank 2010; Selvam and Sivasubramanian 2012). Groundwater remains the only drinking water source in most of Indian rural household. With an estimated 30 million groundwater structures, India is fast hurtling towards a serious crisis of groundwater overuse and quality deterioration (World Bank Report 2010). Groundwater is threatened by several factors related to its mismanagement. Degradation of groundwater quality in coastal region generally occurs due to natural processes such as saline water intrusion, wind driven sea spray and marine aerosols deposited on the top soil, evaporation and interaction of groundwater with brines and sedimentary formation (Sanford et al. 2007). Apart from the natural process, anthropogenic contaminations such as industrial effluents, agricultural fertilizers, municipal waste water, septic tank effluent and landfill are other major causes of water quality deterioration (Mondal et al. 2008; Mondal and Singh 2011; Selvam et al. 2013).

Seawater intrusion is one of the most common problems in almost all coastal aquifers around the globe (Melloul and Goldenberg 1997, 1998; Sivakumar and Elango 2008; Chidambaram et al. 2009; Mondal et al. 2010, 2011; Srinivasamoorthy et al. 2011). This phenomenon can be explained by the variety of conditions like gentle coastal hydraulic gradients, tidal and estuarine activity, sea level rises, low infiltration, excessive withdrawal and local hydrogeological conditions (Sarma et al. 1982; Longe et al. 
1987; Rajmohan et al. 1997, 2000; Barret et al. 2002; Saxena et al. 2004; Kacimov et al. 2009). The common method for assessing seawater intrusion through an aquifer in coastal belts is a periodic analysis of groundwater (Todd 1980; Kim et al. 2009; Mondal et al. 2010, 2011 and Krishnakumar et al. 2012). Chemistry of groundwater is an important factor determining its use for domestic, irrigation and industrial purposes. Interaction of groundwater with aquifer minerals through which it flows greatly controls the groundwater chemistry. Hydrogeochemical processes that are responsible for altering the chemical composition of groundwater vary with respect to space and time. The hydrogeochemical processes of groundwater system help to obtain an insight into the contributions of rock/soil-water interaction (Senthilkumar and Elango 2013). Very few research works have been conducted with the aim of assessing the chemical composition of groundwater in the coastal regions of Tamilnadu. When considering the present study area, so far there is no scientific publication available related to groundwater quality. In this work, a detailed investigation has been carried out to evaluate the geochemical process regulating groundwater quality.

\section{Study area}

Kadaladi block of Ramanathapuram district, Tamilnadu, India lies between the latitude $9^{\circ} 6^{\prime}-9^{\circ} 21^{\prime} \mathrm{N}$ and longitude $78^{\circ} 18^{\prime}-78^{\circ} 45^{\prime} \mathrm{E}$ and covered by the Survey of India Toposheets 58 K/7, 58 K/8, 58 K/11 and 12 (Fig. 1). Total areal extent of the present study area is $623 \mathrm{~km}^{2}$. Presently, Ramanathapuram district is divided into 11 blocks and Kadaladi block is further divided into 60 Panchyat villages. Kadaladi block is mainly covered by sedimentary formation and about $70 \%$ of the study area is covered with Fluvial, Fluvio-Marine, Aeolian and marine sediments of Quaternary age. The Fluvial deposits are made up of sand, silt and clay. The western side of the study area is exposed with Archaean rocks such as Garnetiferous Biotite Gneiss, Quartzite and Charnockites which are intruded later by Pink Granite. The Aeolian deposits are made up of red sands and they are in the form of ancient sand dunes. These dunes run $\sim 10 \mathrm{~km}$ parallel to the coast and extend up to $3 \mathrm{~km}$ across. These sand dunes are separated by marshy deposits of black clays from the sea coast. The sands are underlain by calcareous hardpan. The study area enjoys a tropical climate.

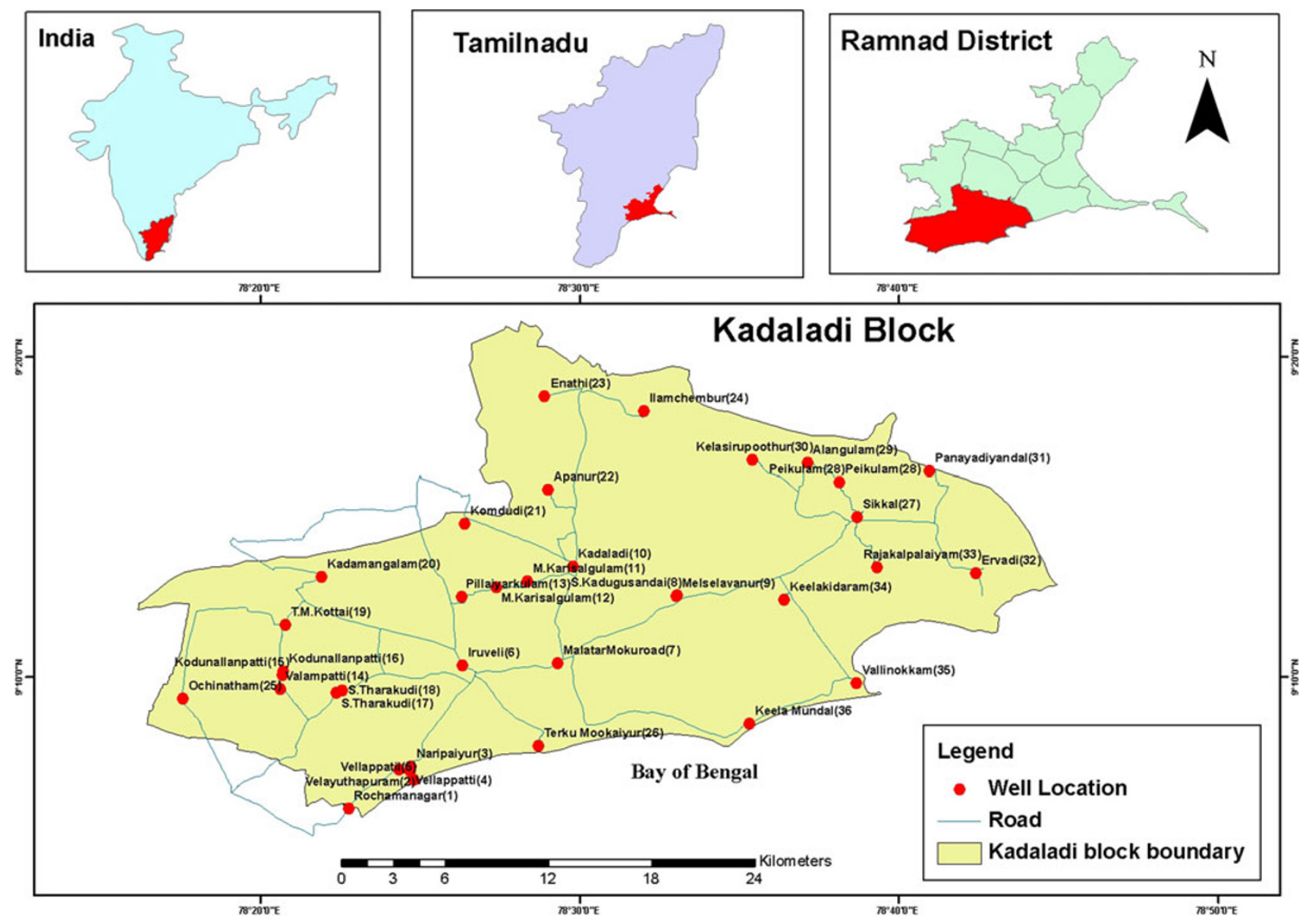

Fig. 1 Location map of the study area 
In the plains, the maximum and minimum temperatures recorded are 39 and $29{ }^{\circ} \mathrm{C}$, respectively. Heat becomes intense in March to September and shoots further up unless interfered by rains. Humidity is relatively high as $79 \%$ on an average and ranges between 80 and $90 \%$ in coastal regions. Coastal areas are flanked by beach ridge complex, swales, swamps and backwater. The sand flat is another feature of the coast comprising clay, silt and often inundated by seawater and encrusted with salt. Major rivers flowing through the study area are Gundar River and Palar River. They flow from northwest to southeast within the study area and enter into Bay of Bengal. The drainage pattern, in general, is dendritic. Both the rivers are seasonal and flow only during monsoon season. In addition to this, a small Kadugusandai Odai also flows through the study area.

The district receives rain under the influence of both southwest and northeast monsoons. The northeast monsoon chiefly contributes to the rainfall in the district. Most of the precipitation occurs in the form of cyclonic storms caused due to the depressions in the Bay of Bengal. The southwest monsoon rainfall is highly erratic and summer rains are negligible. Rainfall data from two stations over the period 1901-2000 were utilized and a perusal of the data shows that the normal annual rainfall over the district is $827 \mathrm{~mm}$ and decreases toward inland. The general practice of people in the study area is to store rain water in tanks and use them for their needs throughout the year (Fig. 2). But most monsoons fail. To cater the need of the people, Tamilnadu Government has established a desalination plant at Naripayur located within the study area. This plant produces good quality drinking water from sea water and supplies them to the surrounding villages.

The alluvium with alternate layers of sand and clay with a thickness of $15-25 \mathrm{~m}$ and are characterized by floating freshwater lenses limited to a depth of 6-7 $\mathrm{m}$ below ground level. It can sustain a pumping of up to $2 \mathrm{~h}$ and can yield about $2-51 / \mathrm{s}$. So people prefer dug wells of 3-6 $\mathrm{m}$ depth than the bore wells of 30 or $50 \mathrm{~m}$ and extract good quality groundwater which floats as lens on the saline water. Comparatively good quality of water is available in the narrow strip of land between red sand dunes running roughly $10 \mathrm{~km}$ parallel to the coast and the coastline (Fig. 3). Natural recharge from rainfall elevates the groundwater level and replenishes the fresh water lens of these sand dune areas. In the study area, there are no deep aquifer has been reported so far. During our reconnaissance survey, we have visited the drilling sites of Mineral Exploration Corporation Ltd (MECL) who were in search of lignite beds. They have not encountered any hard rock or lignite up to the depth of $400 \mathrm{~m}$.

\section{Materials and methods}

\section{Collection of groundwater samples}

Totally 36 wells were identified during our reconnaissance survey for the collection of water samples to carry out chemical analysis. Due care was given to the distribution of wells throughout the study area during well selection. Dug well and bore well samples were collected during the

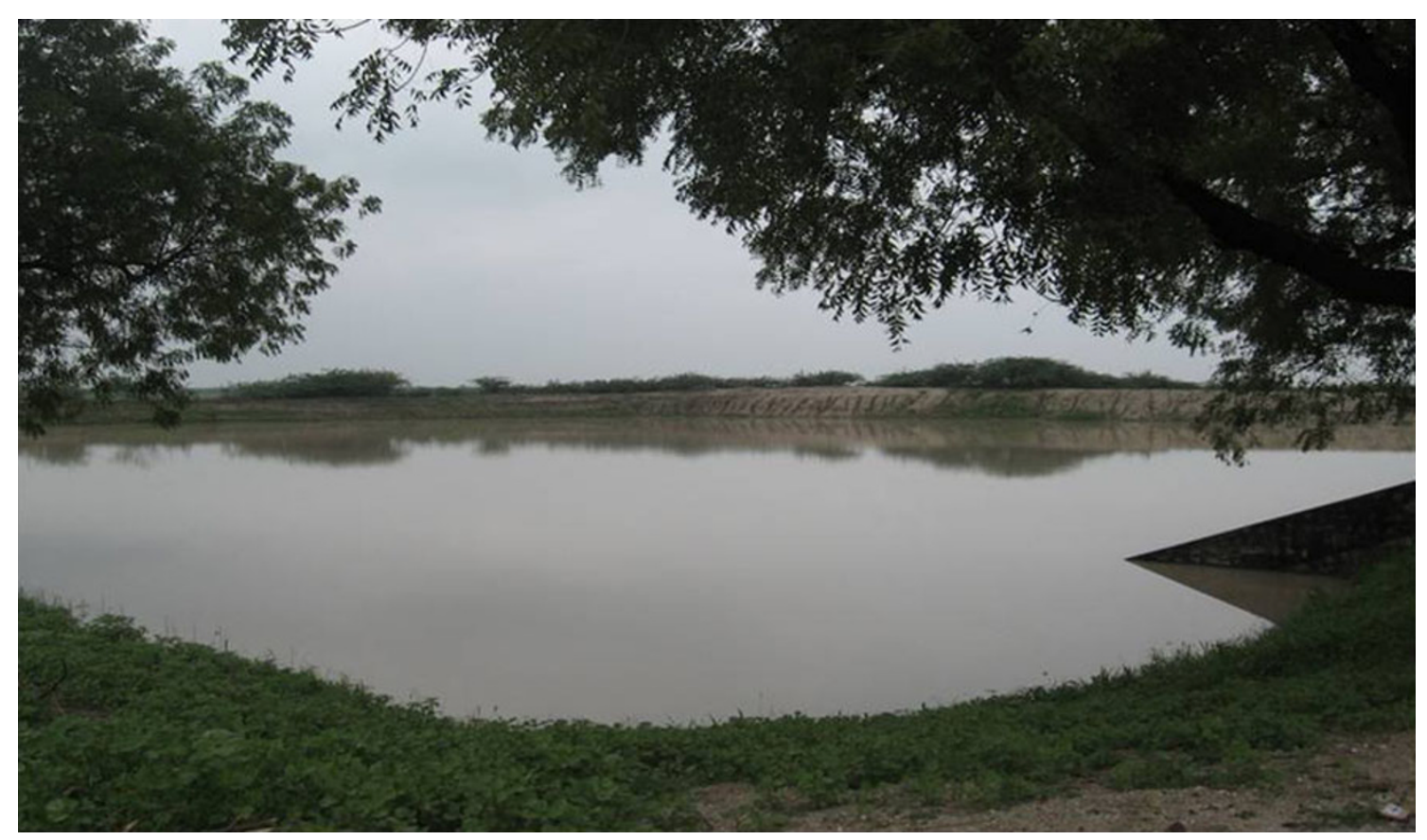

Fig. 2 "Oorani" in the study area 


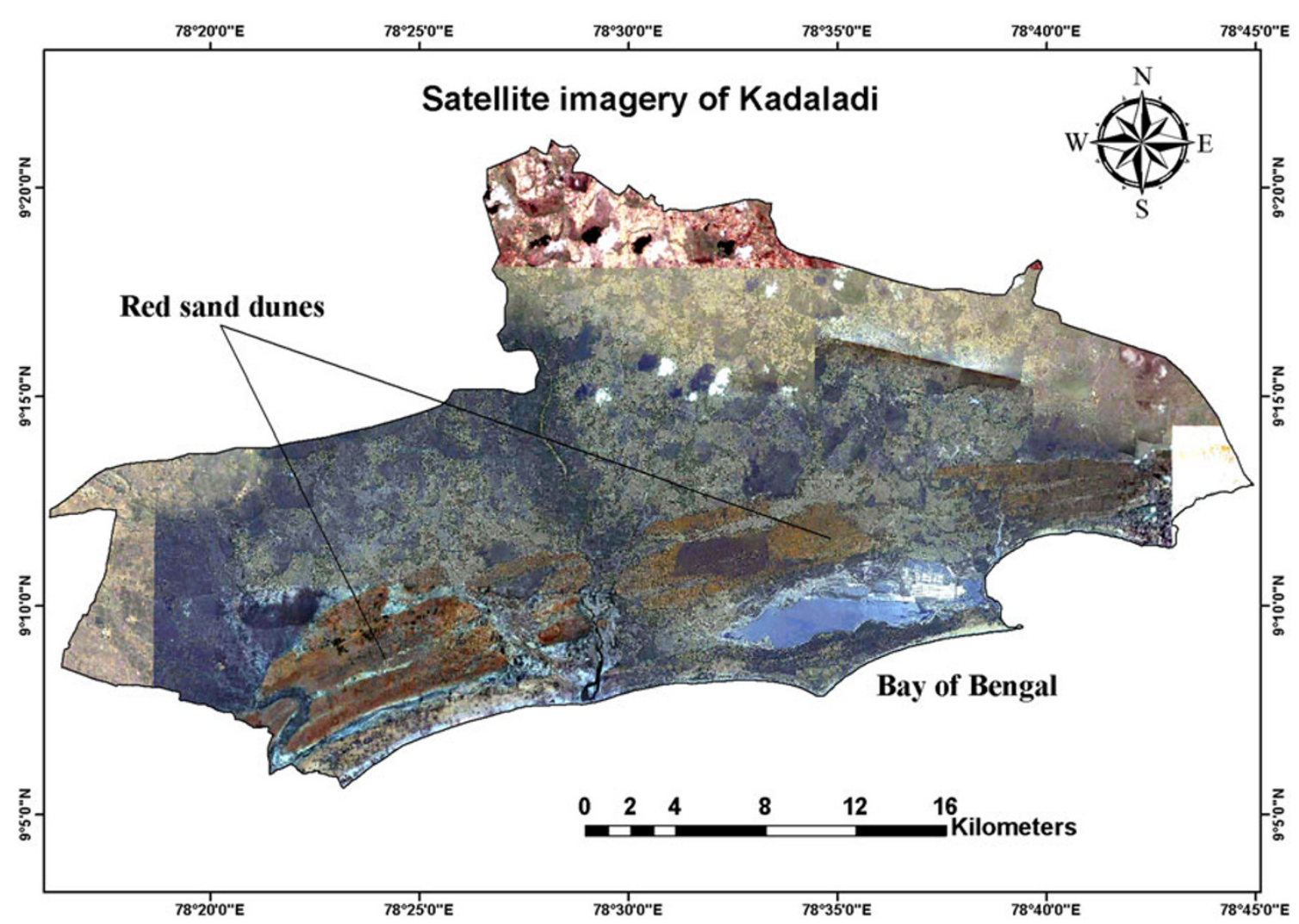

Fig. 3 Satellite image of the study area

pre-monsoon (PRM) period of 2012 (June 2012). Methods of collection and analysis of groundwater samples were essentially the same as given by Brow et al. (1983), APHA (1995). The samples were collected in 11 capacity polythene bottles. Prior to the collection, bottles were thoroughly washed with diluted $\mathrm{HNO}_{3}$ acid, and then with distilled water in the laboratory before filling the bottle with the sample. Portable Eco-testers were used to measure TDS, EC and $\mathrm{pH}$ on-site. The precise locations of the sampling points were also determined in the field using GARMIN 12 Channel GPS. The well locations of the groundwater samples are given in Fig. 1.

\section{Chemical analysis of groundwater}

The groundwater samples collected were analyzed for various physicochemical parameters as described by the American Public Health Association (APHA 1995). Calcium (Ca) and Magnesium $(\mathrm{Mg})$ were determined titrimetrically using standard EDTA; Chloride $(\mathrm{Cl})$ was determined by standard $\mathrm{AgNo}_{3}$ titration; bicarbonate $\left(\mathrm{HCO}_{3}\right)$ was determined by titration with HCL; sodium $\left(\mathrm{Na}^{+}\right)$and potassium $\left(\mathrm{K}^{+}\right)$were determined by Flame Spectrometer; Sulphate $\left(\mathrm{SO}_{4}\right)$ was determined by spectrophotometric turbidimetry. Majority of the analyzed samples show ion balance errors within $\pm 5 \%$, indicating the results are generally acceptable. All concentrations are expressed in milligrams per liter (mg/l), except $\mathrm{pH}, \mathrm{EC}$ and TDS. The EC concentrations were expressed in $\mu \mathrm{S} / \mathrm{cm}$ and TDS concentrations were expressed in ppm. Concentration of chemical parameters of water samples are given in Table 1.

\section{Results and discussion}

\section{General characteristics}

The results of chemical analysis for the groundwater samples collected in June, 2012 are listed in Table 1. Groundwater in the study area is generally alkaline in nature with $\mathrm{pH}$ ranging from 7.2 to 8.2, with an average of 7.8. EC is an indirect measure of ionic strength and mineralization of natural water. EC of groundwater samples of the study area ranges from 190 to $47,600 \mu \mathrm{S} / \mathrm{cm}$, with an average of 8,226 $\mu \mathrm{S} / \mathrm{cm}$. Total dissolved solids (TDS), which is generally the sum of dissolved ionic concentration varies between 116 and $33,320 \mathrm{mg} / \mathrm{l}$ with an average of $5,406 \mathrm{mg} / \mathrm{l}$. Table 1 clearly shows that about $89 \%$ of samples collected falls under brackish water category. Lower $\mathrm{pH}$ (7.2), EC $(190 \mu \mathrm{S} / \mathrm{cm})$ and TDS $(116 \mathrm{ppm})$ has been recorded in the samples collected from Roachmanagar, Velayuthapuram, Vellapatti, M. Karisalkulam and Terku Narippaiyur. Higher 
Table 1 Chemical concentration of major ions

\begin{tabular}{|c|c|c|c|c|c|c|c|c|c|c|c|c|c|}
\hline Sample no & $\mathrm{pH}$ & $\mathrm{EC}$ & TDS & $\mathrm{Na}$ & $\mathrm{K}$ & $\mathrm{Ca}$ & $\mathrm{Mg}$ & $\mathrm{CO}_{3}$ & $\mathrm{HCO}_{3}$ & $\mathrm{Cl}$ & $\mathrm{SO}_{4}$ & $\mathrm{PO}_{4}$ & $\mathrm{NO}_{3}$ \\
\hline 1 & 7.2 & 390 & 238 & 33 & 12 & 38 & 13 & 12 & 183 & 43 & 22 & 0.38 & 0.1 \\
\hline 2 & 7.6 & 670 & 409 & 50 & 5 & 69 & 20 & 12 & 220 & 99 & 41 & 0.27 & 0.18 \\
\hline 3 & 7.8 & 4420 & 2696 & 500 & 210 & 168 & 87 & 24 & 500 & 937 & 252 & 1.1 & 0.42 \\
\hline 4 & 7.8 & 720 & 439 & 58 & 15 & 64 & 26 & 24 & 256 & 85 & 35 & 0.43 & 0.15 \\
\hline 5 & 7.8 & 530 & 323 & 47 & 6 & 43 & 20 & 12 & 183 & 85 & 28 & NA & 0.14 \\
\hline 6 & 7.9 & 2470 & 1507 & 234 & 6 & 61 & 34 & 24 & 464 & 440 & 121 & 0.73 & 0.22 \\
\hline 7 & 7.6 & 4900 & 2989 & 530 & 10 & 131 & 125 & 12 & 354 & 1276 & 230 & 0.92 & 0.32 \\
\hline 8 & 7.7 & 4900 & 2970 & 440 & 10 & 134 & 117 & 12 & 354 & 1276 & 221 & 0.91 & 0.27 \\
\hline 9 & 7.8 & 610 & 372 & 56 & 10 & 34 & 15 & 24 & 268 & 57 & 41 & 0.7 & 0.17 \\
\hline 10 & 7.7 & 2320 & 1415 & 144 & 22 & 90 & 57 & NA & 476 & 425 & 182 & 0.24 & 0.3 \\
\hline 11 & 7.5 & 6900 & 4209 & 550 & 10 & 394 & 232 & NA & 293 & 2028 & 227 & 0.21 & 0.22 \\
\hline 12 & 7.9 & 290 & 177 & 16 & 16 & 24 & 14 & NA & 49 & 28 & 19 & 0.7 & 0.19 \\
\hline 13 & 8 & 490 & 299 & 37 & 13 & 26 & 34 & 24 & 220 & 43 & 17 & 0.7 & 0.22 \\
\hline 14 & 7.4 & 47600 & 33320 & 6500 & 100 & 1872 & 1818 & NA & 342 & 22880 & 1392 & 0.81 & 0.24 \\
\hline 15 & 7.4 & 47600 & 33300 & 6300 & 100 & 1872 & 1838 & NA & 244 & 22865 & 1363 & 0.38 & 0.26 \\
\hline 16 & 7.9 & 190 & 116 & 16 & 5 & 11 & 10 & NA & 98 & 43 & 40 & 0.27 & 0.23 \\
\hline 17 & 7.9 & 2450 & 1495 & 130 & 16 & 120 & 85 & NA & 366 & 525 & 162 & 1.1 & 0.26 \\
\hline 18 & 7.9 & 2450 & 1465 & 128 & 16 & 112 & 88 & NA & 366 & 496 & 153 & 0.92 & 0.1 \\
\hline 19 & 7.5 & 46700 & 32690 & 4500 & 100 & 1860 & 1737 & NA & 366 & 22334 & 1374 & 0.91 & 0.14 \\
\hline 20 & 8.2 & 620 & 378 & 30 & 9 & 35 & 35 & 12 & 293 & 43 & 49 & 0.7 & NA \\
\hline 21 & 7.6 & 8620 & 5258 & 1050 & 210 & 182 & 292 & NA & 390 & 2311 & 445 & 0.43 & 0.1 \\
\hline 22 & 7.9 & 1640 & 1000 & 188 & 8 & 40 & 27 & 12 & 268 & 241 & 226 & 0.34 & NA \\
\hline 23 & 7.9 & 13740 & 8381 & 1760 & 20 & 131 & 249 & NA & 647 & 3276 & 1238 & 0.24 & 0.1 \\
\hline 24 & 7.4 & 730 & 445 & 75 & 15 & 48 & 20 & NA & 317 & 85 & 61 & 1.4 & 0.1 \\
\hline 25 & 7.7 & 11150 & 6802 & 980 & 30 & 832 & 473 & NA & 220 & 1574 & 1756 & 0.6 & 3.9 \\
\hline 26 & 8 & 4730 & 2885 & 510 & 80 & 75 & 106 & NA & 464 & 1120 & 178 & 0.76 & NA \\
\hline 27 & 7.8 & 8680 & 5295 & 1140 & 10 & 189 & 179 & NA & 525 & 2255 & 508 & 0.6 & 0.14 \\
\hline 28 & 8.2 & 25200 & 16632 & 3600 & 300 & 480 & 577 & 12 & 415 & 9394 & 1887 & 0.46 & 0.11 \\
\hline 29 & 8.1 & 8420 & 5136 & 1030 & 20 & 110 & 165 & NA & 378 & 2240 & 422 & 0.1 & NA \\
\hline 30 & 8 & 9160 & 5588 & 980 & 60 & 130 & 191 & NA & 427 & 2623 & 536 & 0.3 & NA \\
\hline 31 & 7.6 & 2880 & 1757 & 300 & 14 & 120 & 72 & NA & 427 & 624 & 220 & 0.43 & NA \\
\hline 32 & 7.9 & 11660 & 7113 & 1500 & 310 & 280 & 246 & NA & 512 & 2879 & 488 & 0.76 & 1.2 \\
\hline 33 & 7.9 & 640 & 390 & 90 & 10 & 24 & 19 & 12 & 293 & 57 & 44 & 0.35 & NA \\
\hline 34 & 7.8 & 4580 & 2794 & 360 & 114 & 149 & 98 & NA & 256 & 1248 & 155 & 0.92 & 1.51 \\
\hline 35 & 8 & 3390 & 2068 & 270 & 134 & 146 & 74 & NA & 342 & 567 & 301 & 0.38 & 12.3 \\
\hline 36 & 8 & 3710 & 2263 & 280 & 110 & 120 & 83 & NA & 427 & 780 & 204 & 0.92 & 5.7 \\
\hline Rainwater & NA & NA & NA & 0.4 & 0.7 & 0.4 & 0.1 & NA & 0.4 & 0.7 & 1.8 & NA & 0.4 \\
\hline Seawater & NA & 52480 & 33588 & 9350 & 688 & 381 & 1270 & NA & 141 & 19300 & 2450 & NA & 8 \\
\hline
\end{tabular}

pH (8.2), EC (47,600 $\mu \mathrm{S} / \mathrm{cm})$ and TDS (33,320 ppm) has been recorded from Valamppatti, T. M. Kottai, Peikulam, Enathi, Komboothi and Ervadi.

Among the cations, the minimum concentration of $\mathrm{Na}$, $\mathrm{Ca}, \mathrm{Mg}$ and $\mathrm{K}$ are $16,11,10$ and $5 \mathrm{mg} / \mathrm{l}$ and the maximum concentrations are 6,500, 1,872, 1,838 and $310 \mathrm{mg} / \mathrm{l}$ respectively. The averages of these cations are 956, 284, 258 and 59 respectively. The order of abundance of these cations is $\mathrm{Na}>\mathrm{Ca}>\mathrm{Mg}>\mathrm{K}$.

\section{Geochemical classification}

Trilinear plotting systems are used to study water chemistry and quality (Piper 1944). On conventional trilinear diagrams sample values for three cations (Calcium, Magnesium and Alkali metals-Sodium and Potassium) and three anions (Bicarbonate, Chloride and Sulfate) are plotted relative to one another. These ions are generally the most common constitutions in unpolluted groundwater. 
Fig. 4 Pipper plot for the groundwater samples

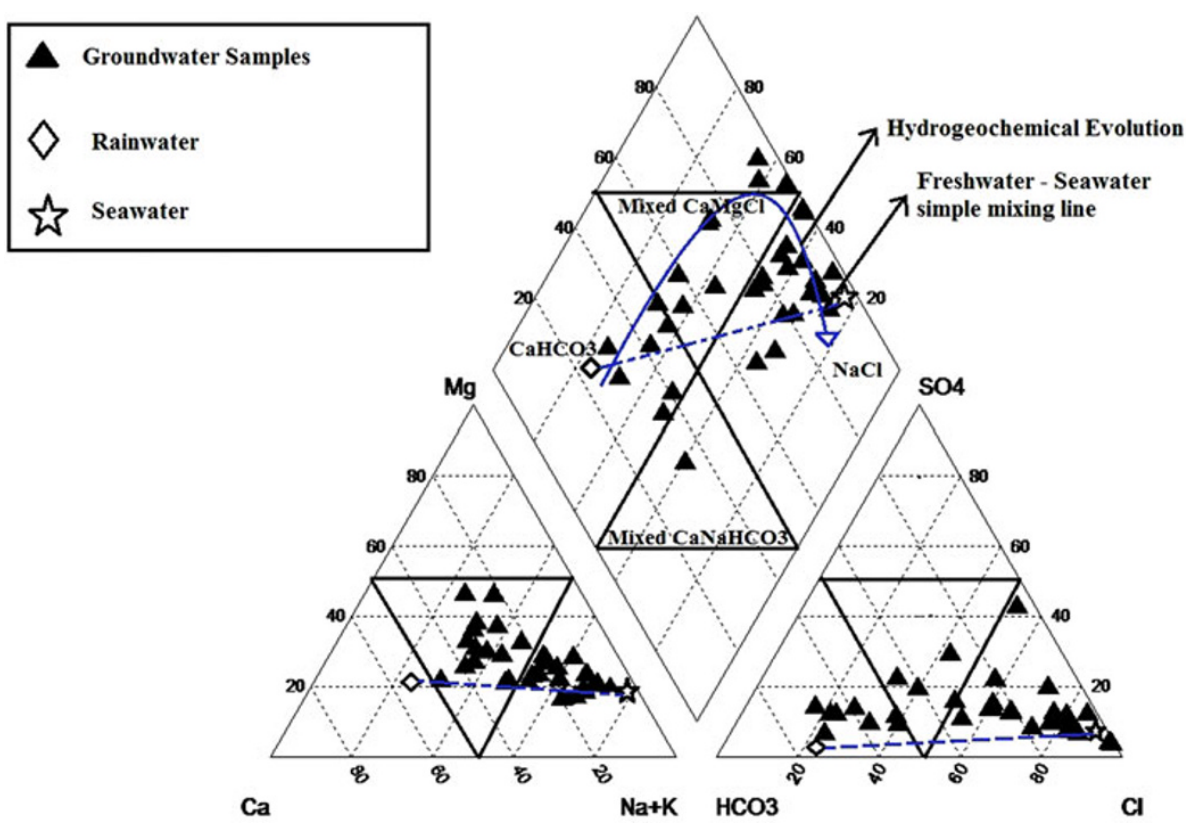

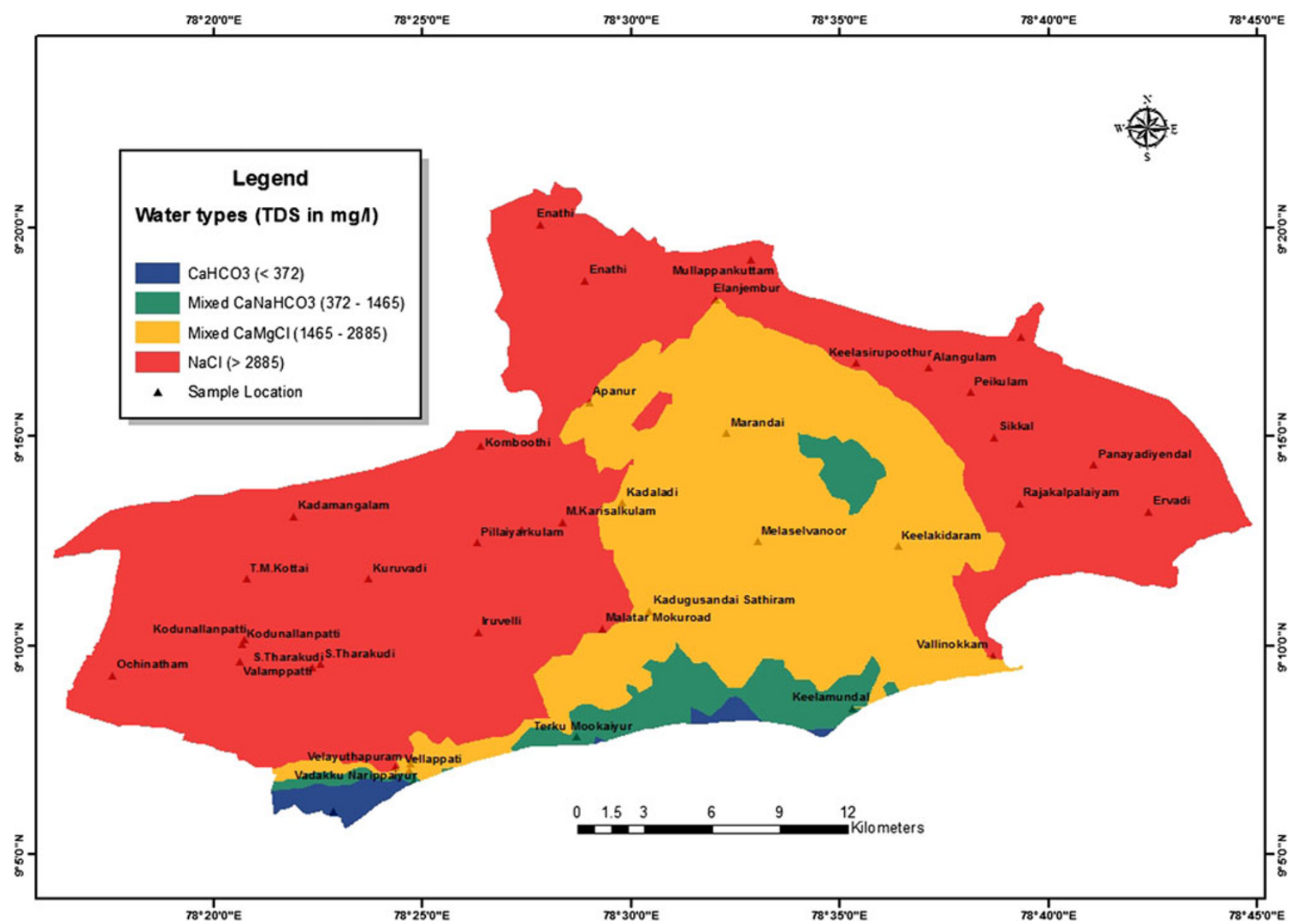

Fig. 5 Spatial distribution of water types 
Fundamental interpretations of the chemical nature of water samples are based on the location of the sample ion values.

Distinct zones within aquifers having defined water chemistry properties are referred to as hydrochemical facies (Vasanthavigar et al. 2010). Determining the nature and distribution of hydrochemical facies can provide insight into how groundwater quality changes within and between aquifers. In Fig. 4 , the $\mathrm{HCO}_{3}-\mathrm{Cl}-\mathrm{SO}_{4}$ anion triangle shows groundwater samples plotted between the bicarbonate type and chloride type end member and Sulfate $\left(\mathrm{SO}_{4}\right)$ is not present in any significant proportion. In $\mathrm{Ca}-\mathrm{Mg}-\mathrm{Na}$ cation triangle samples clustered off-center towards Sodium type groundwater. These two triangles projected onto the main diamond field. If the groundwater is simply mixed with seawater, groundwater composition should be plotted on a straight line connecting the background freshwater and seawater. However, the groundwater in the study area shows a curved path (arrow) of hydrochemical evolution, which starts from the $\mathrm{CaHCO}_{3}$ type via the mixed $\mathrm{CaMgCl}$ type and ends to the $\mathrm{NaCl}$ type. This is a typical pattern which indicates the cation exchange reaction when seawater incursion occurs (Richter et al. 1993). This pattern suggests that the groundwater chemistry in the study area changes due to the cation exchange reaction as well as the simple mixing with seawater as a result of seawater incursion. Figure 5, showing the spatial distribution of groundwater type within the study areas reveals that groundwater available in the coastal sand dunes is comparatively fresh and come under $\mathrm{CaHCO}_{3}$ and mixed $\mathrm{CaNaHCO}_{3}$ type. This type of groundwater may have resulted due the recent recharge of the coastal sand dunes by rainwater. Majority of the groundwater within the study area comes under $\mathrm{NaCl}$ and mixed $\mathrm{CaMgCl}$ type. The higher salinity of the groundwater of the present study area may be due to the mixing of fresh water with relict saline water from a high stand of sea level in past geological time. Since the study area comes under a semi-arid climate, the absence of effective natural flushing activity enhances accumulation of salts and saline water (Cardona et al. 2004).

In addition to Piper diagram, Gibbs plots were also used to gain better insight into hydrochemical processes such as precipitation, rock water interaction and evaporation on groundwater chemistry in the study area. Gibbs (1970) demonstrated that if TDS is plotted against $\mathrm{Na} /(\mathrm{Na}+\mathrm{Ca})$ and $\mathrm{Cl} / \mathrm{Cl}+\mathrm{HCO}_{3}$, this would provide information on the mechanism controlling the chemistry of waters. Figure 6a, b displays that groundwater samples were plotted mostly in the evaporation zone and few samples in the rock water interaction zone. Cation points are scattered. But the anion shows some linear trend because the increase in $\mathrm{Cl}$ and $\mathrm{HCO}_{3}$ may due to the level of mixing of sea water and evaporation. It is expected that as evaporation greatly increases the concentration of ions formed by chemical weathering of subsurface lithology, leading to higher
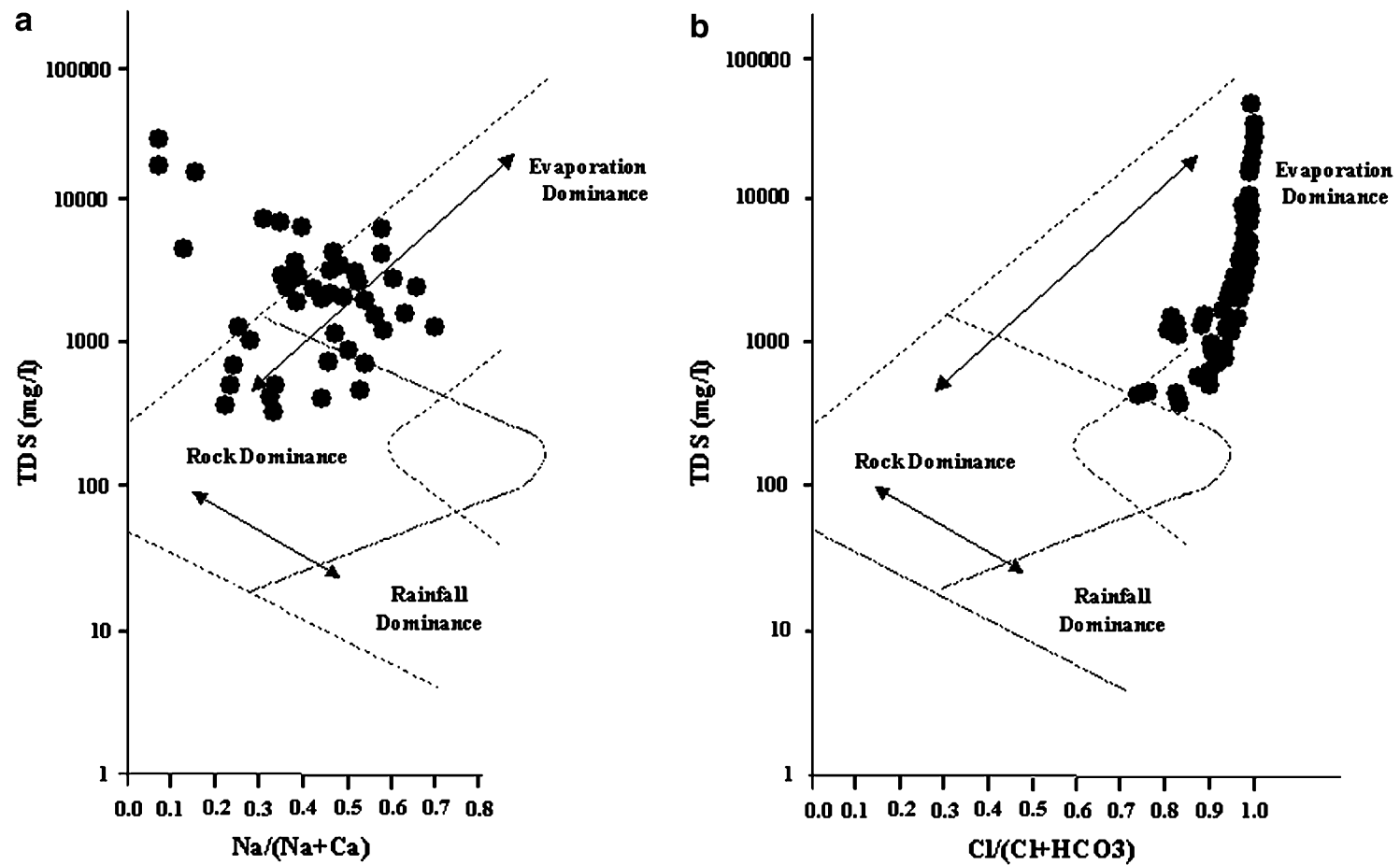

Fig. 6 a, b Mechanism controlling groundwater chemistry

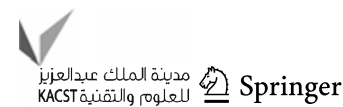


salinity (Volker 1961; Stuyfzand P 1993). Both Piper and Gibbs suggest that groundwater chemistry is mainly regulated by mixing of high saline water and evaporation.

\section{Geochemical process}

The compositional relations among the dissolved ions can be used to assess the origin of solutes and the processes that results in water composition. The chemical data of groundwater samples are plotted on $\mathrm{Na}$ Versus $\mathrm{Cl}$ scatter plot. The $\mathrm{Na} / \mathrm{Cl}$ relationship has often been used to identify the mechanism for acquiring salinity and saline intrusions.
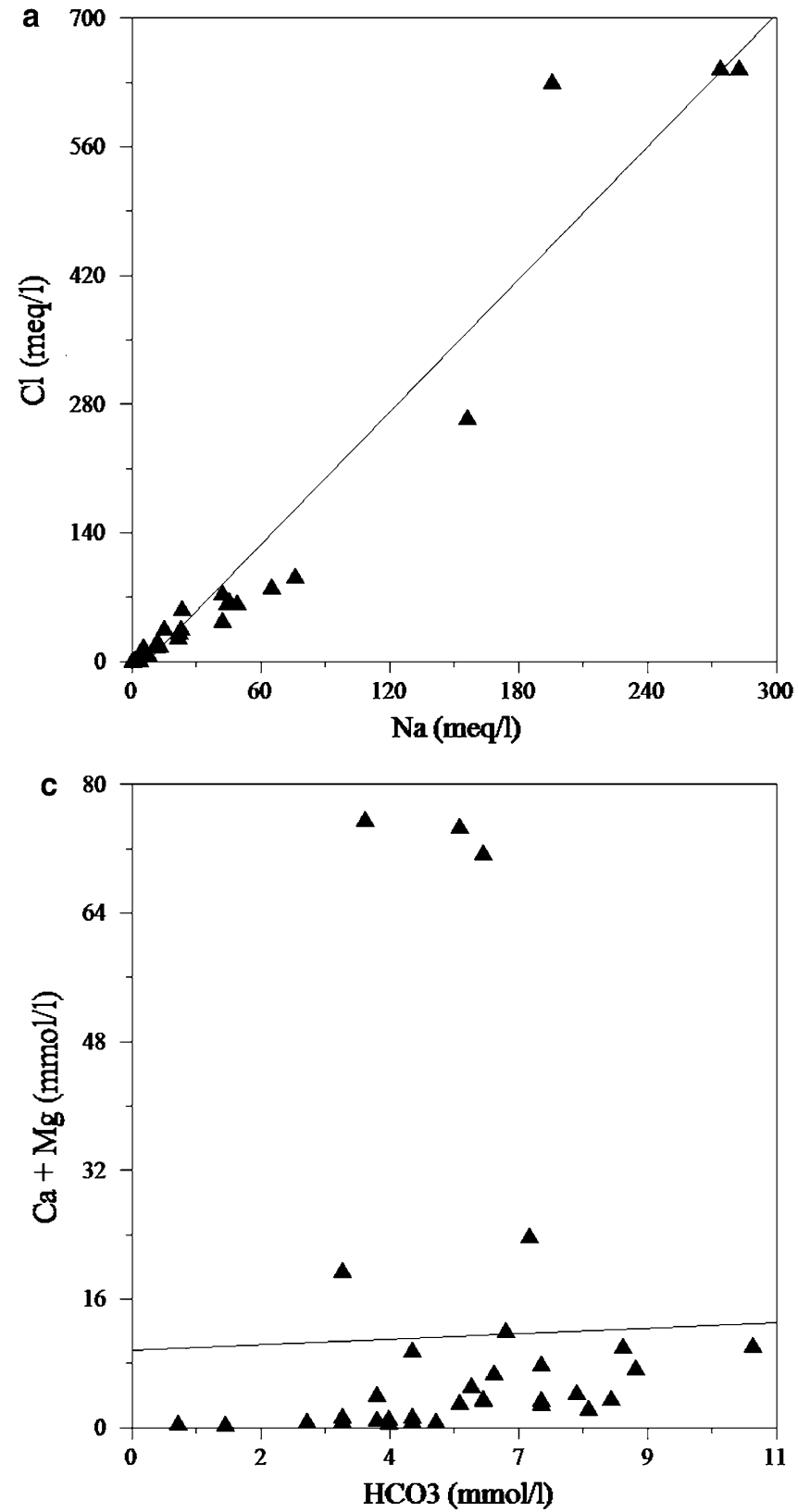

Fig. 7 Ionic scatter diagram of groundwater in the study area
Sodium and Chloride show a good correlation (Fig. 7a), indicating groundwater are probably controlled by waterrock interaction, most likely derived from the weathering of calcium-magnesium silicates, chiefly from calcite, plagioclase, gypsum and feldspar (Srinivasamoorthy et al. 2011). However, increased concentration of $\mathrm{HCO}_{3}$ compared to $\mathrm{Na}$ concentration (Fig. $7 b$ ) in groundwater suggests that silicate weathering also occurs (Fisher and Mullican 1997).The evolution of the slopes of $\mathrm{Ca}$ and $\mathrm{Mg}$ with $\mathrm{HCO}_{3}$ gives valuable information about the sources of $\mathrm{Ca}$ and $\mathrm{Mg}$ in groundwater (Richter et al. 1993). $\mathrm{Ca}+\mathrm{Mg}$ Versus $\mathrm{HCO}_{3}$ plot (Fig. 7c) shows a horizontal trend line
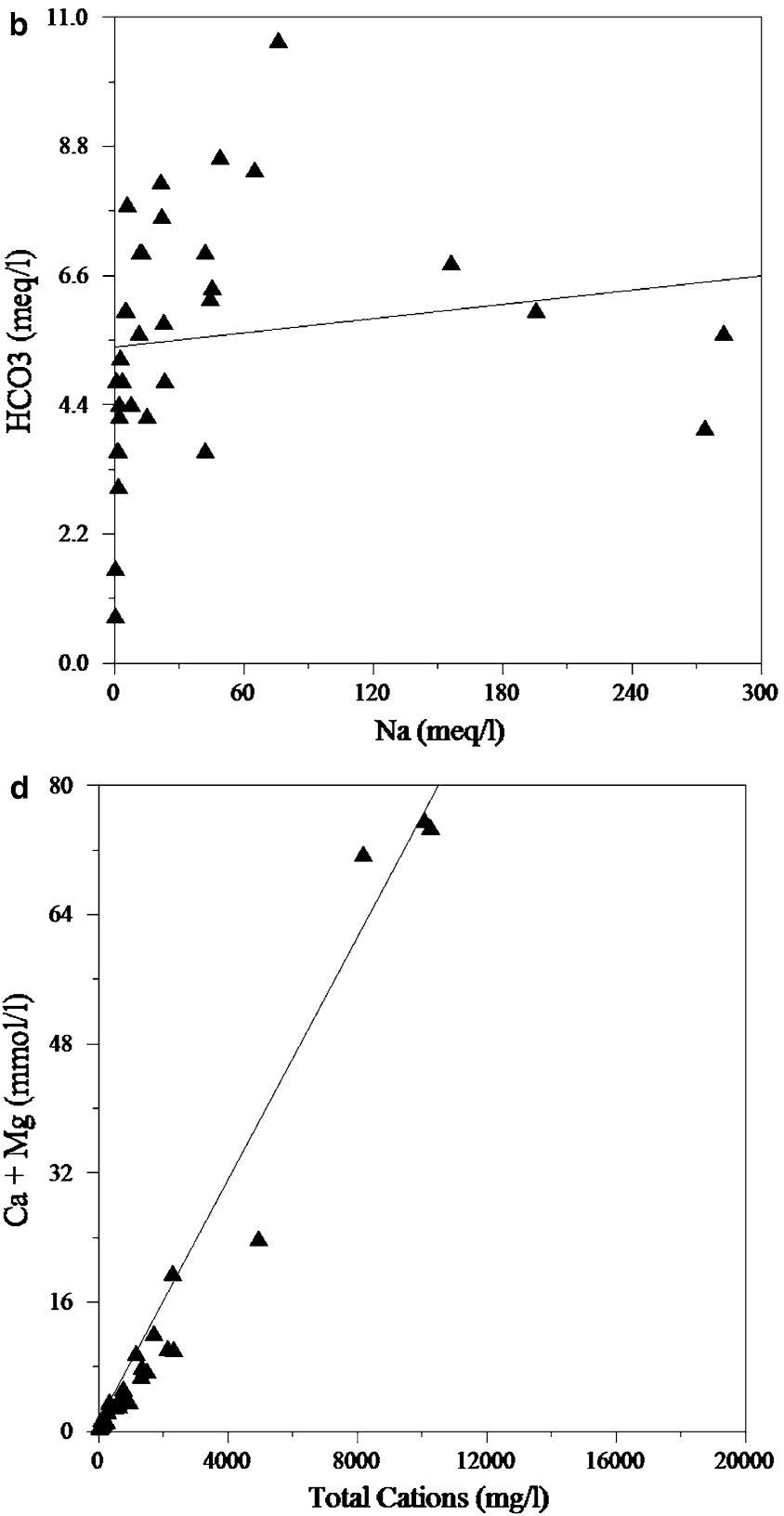


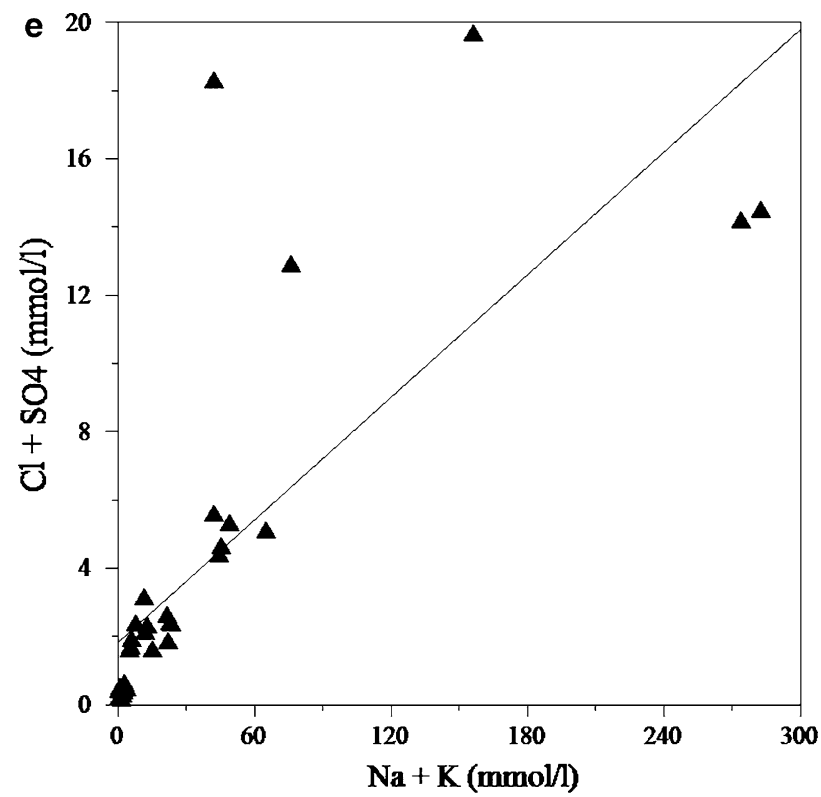

Fig. 7 continued

indicating that $\mathrm{Ca}+\mathrm{Mg} / \mathrm{HCO}_{3}$ ratio does not change during the increase of $\mathrm{HCO}_{3}$. This indicates contribution of $\mathrm{Ca}+\mathrm{Mg}$ and $\mathrm{HCO}_{3}$ are from different sources. Feldspars present in the sand and the clay minerals in the black soil may be the source for $\mathrm{Ca}$ and $\mathrm{Mg}$. Higher $\mathrm{HCO}_{3}$ may because of the higher evaporation and the presence of Kankar. Enrichment of $\mathrm{HCO}_{3}$ and depletion of $\mathrm{Ca}+\mathrm{Mg}$ may be due to cation exchange (Spears 1986). The plot of $\mathrm{Ca}+\mathrm{Mg}$ versus total cations shows that the data falls on the 1:1 trend line, reflecting $\mathrm{Na}$ and $\mathrm{K}$ as the major contributor for the increase of TDS (Fig. 7d). From Fig. 7e, increase in Alkalinity corresponds to the simultaneous increase of $\mathrm{Cl}+\mathrm{SO}_{4}$ suggesting a common source for these ions. The increased $\mathrm{Na}$ content which is an index of weathering suggests that ions result from silicate weathering or dissolution of soil salts, the excess of $\mathrm{Na}+\mathrm{K}$ over $\mathrm{Cl}$ suggests silicate weathering and also suggests the higher concentration of Alkalis is from sources and precipitation (Singh et al. 2011). The $\mathrm{Na}+\mathrm{K}$ versus Total cations scatter diagram (Fig. 7f) of the study area shows most of the sample points falling below the trend line. This suggests that the cations in the groundwater might have been derived from silicate weathering.

\section{Conclusion}

In this study, an attempt has been made to evaluate the geochemical processes regulating groundwater quality in the coastal region of Kadaladi block, Ramanathapuram district, Tamilnadu, India. For this study, 36 groundwater samples were collected and analyzed for $\mathrm{pH}, \mathrm{EC}$, TDS and

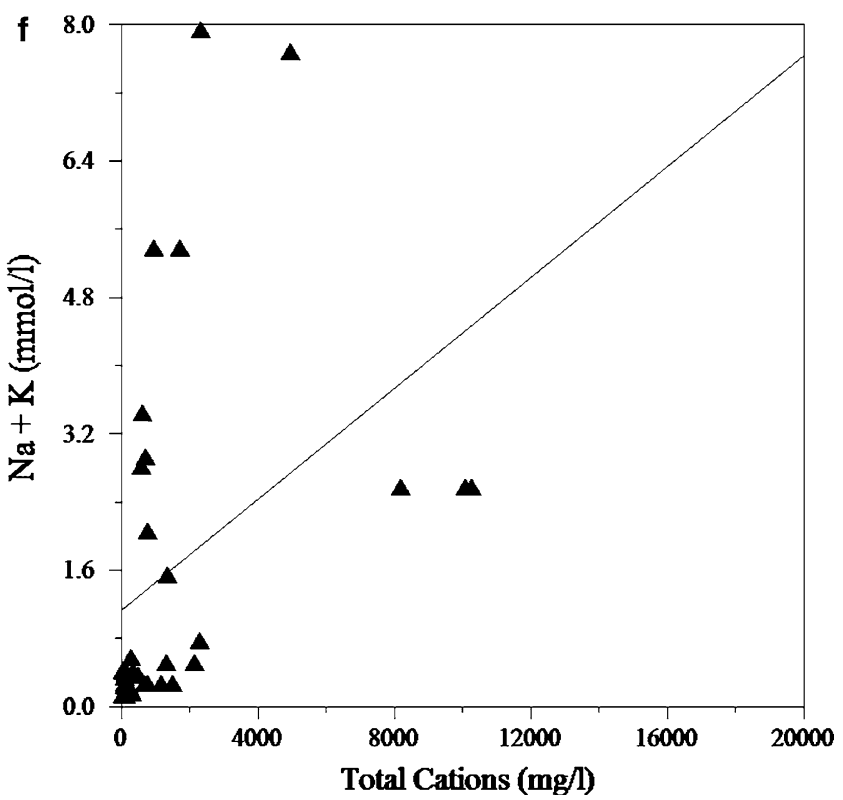

major ions. The order of abundance of ions are $\mathrm{Na}>$ $\mathrm{Ca}>\mathrm{Mg}>\mathrm{K}$ and $\mathrm{Cl}>\mathrm{HCO}_{3}>\mathrm{SO}_{4}>\mathrm{NO}_{3}>\mathrm{PO}_{4}$. Geochemical facies of classification of groundwater shows most of the samples are $\mathrm{Na}-\mathrm{Cl}$ type and the remaining samples are mixed $\mathrm{Ca}-\mathrm{Mg}-\mathrm{Cl}$ type. This suggests mixing of high saline water which generally indicates a strong sea water influence. The scatter plot $\mathrm{Na} / \mathrm{Cl}$ shows good correlation indicating the groundwater chemistry is probably controlled by rock-water interaction. The plot of $\mathrm{Ca}+\mathrm{Mg}$ / $\mathrm{HCO}_{3}$ shows enrichment of $\mathrm{HCO}_{3}$ than $\mathrm{Ca}+\mathrm{Mg}$ suggesting both are from different sources. In addition with Piper diagram and Scatter plots, Gibbs plots were also used to understand the hydrochemical processes. In the Gibbs plots, most of the samples fall in evaporation dominance zone. Present study describes a wide range of salinity values which are noticed in the study area. This is due to the wide range of sediment permeability that occurs in the coastal plain may result in the incomplete flushing of the relict salinity. Higher salinity of groundwater distributed within the study area may be due to mixing of fresh water with relict saline water due to a higher stand of sea level in past geological time. In addition to saline incursion, hydrochemistry is also controlled by rock-water interaction followed by the concentration of these ions by evaporation. The coastal sand dunes running parallel to coast for roughly $30 \mathrm{~km}$ are recharged with recent meteoric water. Hence, good quality of groundwater is restricted only to coastal dune within the study area and it is important to conserve these dunes. This is well reflected in the spatial distribution of hydrochemical facies map (Fig. 5). To further pin point the origin of the salinity, trace element and isotope studies are warranted. 
Acknowledgments The authors are thankful to the Department of Science and Technology, Ministry of Science and Technology, Government of India for providing the financial assistance to carry out the work under WAR for Water scheme. We extend our sincere thanks to anonymous reviewers for their valuable suggestions to improve the quality of the paper.

Open Access This article is distributed under the terms of the Creative Commons Attribution License which permits any use, distribution, and reproduction in any medium, provided the original author(s) and the source are credited.

\section{References}

APHA (1995) Standard methods for the examinations of water and wastewater, 19th edn. American Public Association, Washington

Barret B, Heinson G, Hatch M, Telfer A (2002) Geophysical methods in saline groundwater studies: locating perched water tables and fresh-water lenses. Explor Geophys 33:115-121

Brow E, Skougstad MW, Fishmen MJ (1983) Method for collection and analyzing of water samples for dissolved minerals and gases. U.S. Govt, Washington, p 75

Cardona A, Carrillo-Rivera JJ, Huizar A' lvarez R, Graniel-Castro E (2004) Salinization in coastal aquifers of arid zones: an example from Santo Domingo, Baja California Sur, Mexico. Environ Geol 45:350-366

Chidambaram S, Senthil Kumar G, Prasanna MV, John Peter A, Ramanthan AL, Srivasamoorthy K (2009) A study on the hydrogeology and hydrogeochemistry of groundwater from different depths in a coastal aquifer: Annamalai Nagar, Tamilnadu, India. Environ Geol 57:59-73

Fisher RS, Mullican FW (1997) Hydrochemical evolution of sodiumsulfate and sodium-chloride groundwater beneath the Northern Chihuahuan Desert, Trans- Pecos, Texas, USA. Hydrogeol J 10(4):455-474

Gibbs RJ (1970) Mechanisms controlling world water chemistry. Science 17:1088-1090

Kacimov AR, Sherif MM, Perret JS, Al-Mushikhi (2009) Control of sea-water intrusion by salt-water pumping: Coast of Oman. Hydrogeol J 17(3):541-558. doi:10.1007/s10040-008-0425-8

Kim KL, Park YS, Kim GP, Park KH (2009) Dynamic freshwatersaline water interaction in the coastal zone of Jeju Island, South Korea. Hydrogeol J 17:617-629

KrishnaKumar S, Chandrasekar N, Seralathan P, Prince S, Godson MNS (2012) Hydrogeochemical study of shallow carbonate aquifers, Rameswaram Island, India. Environ Monit Assess 184(7):4127-4138

Longe EO, Malomo S, Olorunniwo MA (1987) Hydrogeology of lagos metropolis. Afr J Earth Sci Technol 6(2):163-174

Melloul AJ, Goldenberg LC (1997) Monitoring of seawater intrusion in coastal aquifers: basics and local concerns. J Environ Manage $51: 73-86$

Melloul LC, Goldenberg AJ (1998) Early-indicator signals of groundwater contamination: the case study of seawater encroachment. Environ Geol 33(4):279-288

Mondal NC, Singh VP (2011) Hydrochemical analysis of salinization for a tannery belt in Southern India. J Hydro 405(2-3):235-247

Mondal NC, Saxena VK, Singh VS (2008) Occurrence of elevated nitrate in groundwaters of Krishna delta, India. African J Environ Sci Tech 2(9):265-271

Mondal NC, Singh VP, Singh VS, Saxena VK (2010) Determining the interaction between groundwater and saline water through groundwater major ions chemistry. J Hydro 25:100-111
Mondal NC, Singh VP, Singh VS (2011) Hydrochemical characteristic of coastal aquifer from Tuticorin, Tamilnadu, India. Environ Monit Assess 175:531-550. doi:10.1007/s10661-010-1549-6

Natarajan R (1997) Seasonal and spatial variation in magnesium and chloride concentration in groundwater of Nagai Quaid-E-Milleth district, Tamil Nadu, South India. Indian J Environ Prot 17(6): $448-453$

Piper AM (1944) A graphic procedure in the geochemical interpretation of water analysis. Trans Am Geophys Union 25:914-923

Rajmohan N, Elango L, Ramachandran S, Natrajan M (2000) Major ion correlation in groundwater of Kancheepuram Region, South India. Indian J Environ Prot 20(3):188-193

Richter BC, Kreitler CW, Bledsoe BE (1993) Geochemical techniques for identifying sources of groundwater salinization. CRC, New York, 272p

Sanford W, Langevin C, Polemio M, Povinec P (2007) A new focus on groundwater-seawater interactions, vol 312. IAHS Publications. ISBN 978-1-901502-04-6

Sarma VVJ, Prasad NVBSS, Prasad R (1982) The geochemistry of groundwater along Visakhatnam-Bhimilipatnam coast with regard to their utility in drinking, domestic and irrigation purposes. J Explor Geophy 2(4):37-52

Saxena VK, Mondal NC, Singh VS (2004) Identification of sea-water ingress using strontium and boron in Krishna Delta, India. Curr Sci 86:586-590

Selvam S, Sivasubramanian P (2012) Groundwater potential zone identification using geoelectrical survey: a case study from Medak District, Andhra Pradesh, India. Inter J Geomat Geosci 3(1):55-62

Selvam S, Manimaran G, Sivasubramanian P (2013) Hydrochemical characteristics and GIS-based assessment of groundwater quality in the coastal aquifers of Tuticorin corporation, Tamilnadu, India. Appl Water Sci 3:145-159

Senthilkumar M, Elango L (2013) Geochemical processes controlling the groundwater quality in lower Palar river basin, Southern India. J Earth Syst Sci 122(2):419-432

Singh A, Tewary BK, Sinha A (2011) Hydrochemistry and quality assessment of groundwater in part of Noida metropolitan city, Uttarpradesh. J Geol Soc India 78:523-540

Sivakumar C, Elango L (2008) Assessment of water quality in kalpakkam region, Tamil Nadu. Nat Environ Poll Technol 7(4):687-691

Spears DA (1986) Mineralogical control of the chemical evolution of groundwater. In: Trudgill ST (ed) Solute processes. Wiley, Chichester, 512p

Srinivasamoorthy K, Vasanthavigar M, Chidambaram S, Anandhan P, Sarma VS (2011) Characterisation of groundwater chemistry in an eastern coastal area of Cuddalore district, Tamil Nadu. J Geo1 Soc India 78(6):549-558

Stuyfzand PJ (1993) Hydrochemistry and hydrology of the coastal dune area of the western Netherlands. Vrije Universiteit, Amsterdam

Todd DK (1980) Groundwater hydrology, 2nd edn. Wiley, New York

Vasanthavigar M, Srinivasamoorthy K, Vijayaragavan K, Rajiv Ganthi R, Chidambaram S, Anandhan P, Manivannan R, Vasudevan S (2010) Application of water quality index for groundwater quality assessment: Thirumanimuttar sub-basin, Tamilnadu, India. Environ Monit Assess 171:595-609. doi:10.1007/s10661-009-1302-1

Volker A (1961) Source of brackish ground water in pleistocene formations beneath the dutch polderland. Economic Geol 56:1045-1057

World Bank Report (2010) Deep wells and prudence: towards pragmatic action for addressing groundwater overexploitation in India. The World Bank, Washington Report No. 51676 